\title{
Contact Fatigue Strength of Austempered Ductile Iron (ADI) in Gear Applications
}

\author{
Fabian Goergen ${ }^{1, *} \mathbb{C}$, Dieter Mevissen ${ }^{1}$, Stefano Masaggia ${ }^{2}$, Enrico Veneri ${ }^{2}$, Jens Brimmers ${ }^{1}(\mathbb{D}$ \\ and Christian Brecher ${ }^{1}$ \\ 1 Laboratory for Machine Tools and Production Engineering (WZL) of RWTH Aachen University, \\ 52074 Aachen, Germany; d.mevissen@wzl.rwth-aachen.de (D.M.); j.brimmers@wzl.rwth-aachen.de (J.B.); \\ c.brecher@wzl.rwth-aachen.de (C.B.) \\ 2 Zanardi Fonderie Società per Azioni, 37046 Minerbe VR, Italy; mst@zanardifonderie.com (S.M.); \\ env@zanardifonderie.com (E.V.) \\ * Correspondence: f.goergen@wzl.rwth-aachen.de; Tel.: +49-241-80-25372
}

Received: 29 July 2020; Accepted: 21 August 2020; Published: 25 August 2020

\begin{abstract}
Austempered Ductile Iron (ADI) is widely implemented to achieve lightweight and optimized components in power transmissions (e.g., internal gear in planetary stages), by substituting steel castings or a combination of Ductile Iron and steel-assembled structures. In this paper, the contact fatigue of two ADI grades (ADI J/S900-8; ADI J/S1200-3) is investigated by disk-on-disk tests. The disk-on-disk contact is an analogy model of the tooth contact and represents the tribological conditions at a specific point on the path of contact. The experimental results cover the endurance limit as well as the short time fatigue behavior for both ADI variants. In addition, the pitting characteristics and microstructural changes are analyzed in order to get a further understanding of the fatigue behavior of ADI.
\end{abstract}

Keywords: austempered ductile iron; ADI; gear load capacity; contact fatigue; ADI JS/900-8; ADI JS/1200-3; twin-disk test rig; disk-on-disk test rig

\section{Introduction}

Due to rising demands for a higher power density and the continuous pressure on production costs, there is a large potential for new materials in gear applications. In the power transmission sector, Austempered Ductile Iron (ADI) is in particular widely implemented in order to achieve lightweight and optimized components, by substituting steel castings or combination of Ductile Iron and steel-assembled structures [1-3]. Regarding the comparison of the fracture strength to the breaking elongation, ADI covers a field that is just in between case-hardened steel and nodular cast iron (Figure 1). The unique microstructure of ADI results in material properties that are comparable to conventional structural steels. ADI's strength, combined with a lower specific weight at the solid state and a lower viscosity at the melt state, allows one to obtain lightweight and material-efficient components that substitute for high-strength steels and aluminum alloys.

Besides the structural components such as planetary carriers or housing, ADI shows a high potential for rolling-sliding contacts because of its high wear resistance. Several studies investigated the rolling contact fatigue behavior of ADI and showed the potential of a high contact fatigue strength [4-6]. In terms of pursuing an integrated design of different functional components, the housing and ring gear of a planetary gearbox constitute a good example of the advantages of ADI (Figure 1) [7-9]. In this case, the assembly space, number of parts and, therefore, the production costs can be reduced. In fact, ADI's advantages are enhanced when all its properties can be used in the same component. 
Material substitution requires a careful and accurate design based on reliable material properties to guarantee the appropriate safety factors. The effort of material suppliers to provide engineers an open material database is fundamental and mandatory. This paper will give an overview of the technological material properties and the contact fatigue behavior of ADI when compared to common steel. The considered approach is to give holistic information about ADI applied to rolling-sliding contacts, rather than providing a specific focus on a certain ADI grade. The focus in this paper is to investigate the rolling contact fatigue behavior of ADI with the purpose of applying ADI to gears.

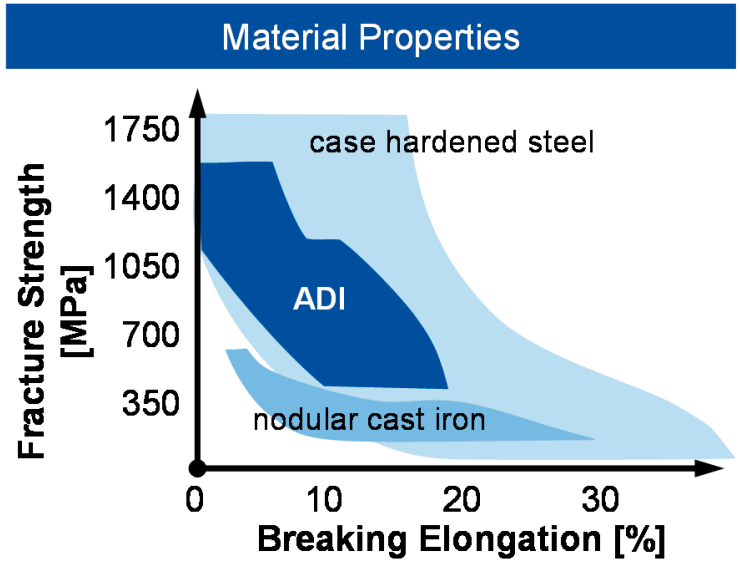

Application Field

\section{Rolling-Sliding Contacts}

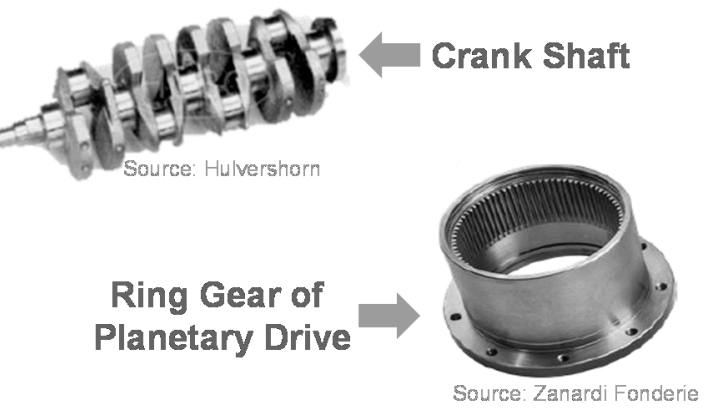
High ratio between fracture
strength and breaking elonguation
High wear resistance

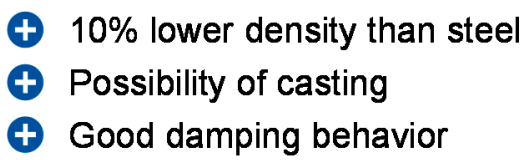

Figure 1. Introduction and motivation of austempered ductile iron (ADI) in applications [2].

\section{Objective and Approach}

A sufficient load capacity is the most important requirement when designing a gear stage. During tooth meshing, the gear is loaded with two completely different types of stresses. On the one hand, the tooth root is bent, and on the other hand there is a rolling-sliding of both tooth flanks on each other. Therefore, suitable gear materials, in combination with the manufacturing chain, have to provide a sufficient bending as well as contact strength. For ring gears in particular, austempered ductile iron (ADI) can be an attractive alternative material when compared to existing gear steel (such as tempered steels) because of the possibility of casting and the high breaking elongation [10]. To establish a new material in gear applications, research on rolling-sliding contact fatigue is mandatory as a first step, in order to support engineers with reliable design guidelines for new materials.

The objective of this paper is the determination and evaluation of the rolling-sliding contact fatigue of different ADI grades (JS/ADI900-8 and JS/ADI1200-3) (Figure 2). The focus of this paper is to determine the rolling-sliding contact fatigue for gear applications designed with the European standard ISO 6336 [11,12]. For this purpose, endurance strength limits for pitting and bending fatigue need to be derived by experimental testing. For an efficient screening and comparison in the first step, a disk-on-disk contact is used as an analogy test for the tribological system's "tooth flank contact". For each variant, a complete $\mathrm{S} / \mathrm{N}$ curve is presented. In order to develop a deeper understanding of contact fatigue mechanisms, the different materials are analyzed in terms of damage pattern, wear properties and changes in microstructure. Finally, the endurance limits for the ADI grades and the quenched and tempered steel $42 \mathrm{CrMo} 4$ are compared to the maximum HerTZIAN pressure.

Figure 2 shows the research approach. In the first step, the manufacturing and analysis of the test parts for the disk-on-disk contact fatigue tests is carried out. The quality control includes measurements of the hardness, microstructure, geometry and surface roughness of the contact area. In the second 
step, the contact fatigue is investigated on the disk-on-disk test rig, including the endurance limit and the finite life region. The endurance limit is determined by the stair case method [13], whereas the finite life is investigated on two constant load levels [14]. In the last step, the different S/N curves are compared to each other and are also classified to common case-hardened steel. A further analysis includes the change of the microstructure and hardness caused by the loading.

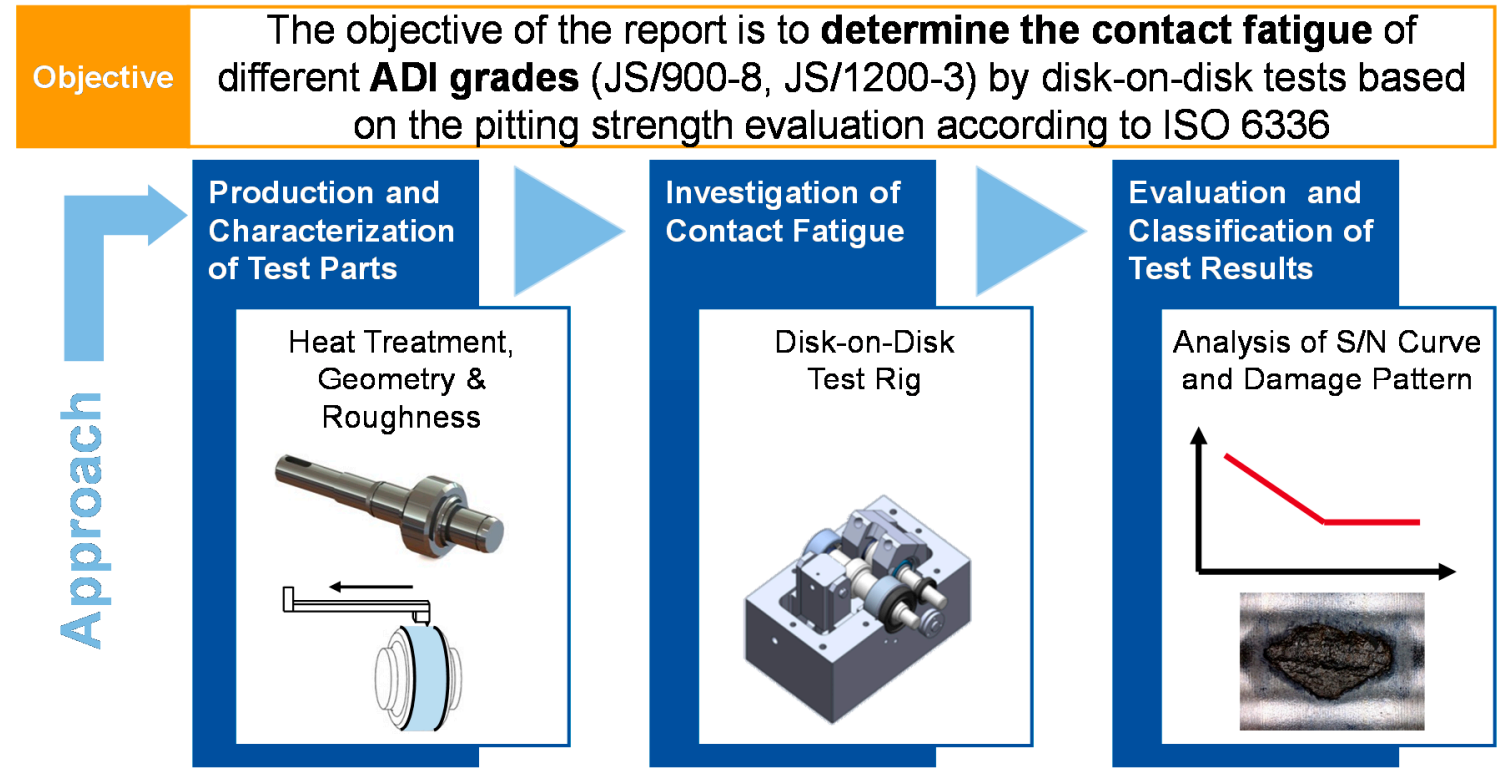

Figure 2. Objective and Approach.

\section{Test Parts, Test Rigs and Test Conditions}

\subsection{Test Parts}

The production of the test parts followed the conventional process chain of ADI parts, as shown in Figure 3. The starting point was the casting process and heat treatment, followed by the cutting processes of turning and milling. Finally, the functional surface (bearing seats and contact area of disks) were ground. Starting with the casting, the casting geometry and the feeding system were adapted in order to achieve a good quality in the contact area of the disk and to avoid influences of possible internal defects. The chemical compositions of both material grades (ADI JS/900-8 and JS/1200-3) were measured from particles taken from the production line (Table 1). All samples were cast in the same batch, with a nodule count of $140 \mathrm{Nod} / \mathrm{mm}^{2}$.

Table 1. Chemical composition of the casting batch.

\begin{tabular}{cccccc}
\hline Carbon & Silicon & Manganese & Copper & Nickel & Molybdenum \\
\hline C [wt.\%] & Si [wt.\%] & Mn [wt.\%] & Co [wt.\%] & Ni [wt.\%] & Mo [wt.\%] \\
\hline 3.56 & 2.44 & 0.20 & 0.65 & 1 & 0.26 \\
\hline
\end{tabular}

The subsequent heat treatment is the most important step of the manufacturing chain, since the final mechanical properties are determined in this step. ADI was obtained by heat-treating an alloyed Pearlitic Ductile Iron. The alloying elements are typically Copper, Nickel and Molybdenum. The quantity of alloying elements depends on the casting's relevant thickness and provides the right hardenability during the heat treatment [7,9]. The heat treatment consists of two steps: first, a full austenitization stage, and then a final isothermal quenching in molten salts for the duration that is needed to ensure the completion of the ausferritic reaction and before the precipitation of bainitic carbides, as shown in Figure 3 on the left. This time frame is called the "Process Window". 
The samples were heat-treated in two batches in order to obtain the two different grades. In this paper, the heat treatment for the grades ADI JS/900-8 and JS/1200-3 consisted in austenitization within a temperature range of $T_{\text {Austenit }}=890-920^{\circ} \mathrm{C}$ and quenching in molten salt within a temperature range of $T_{A D I 900}=350-390{ }^{\circ} \mathrm{C}$ for ADI JS/900-8 and $T_{A D I 1200}=300-340{ }^{\circ} \mathrm{C}$ for ADI JS/1200-3 (Nomenclature in Table A1, Appendix A). The overall duration of the heat treatment was under three hours. The microstructure after the heat treatment of both ADI grades is shown in Figure 3. The microstructure shows the ausferritic matrix containing black circular nodules.
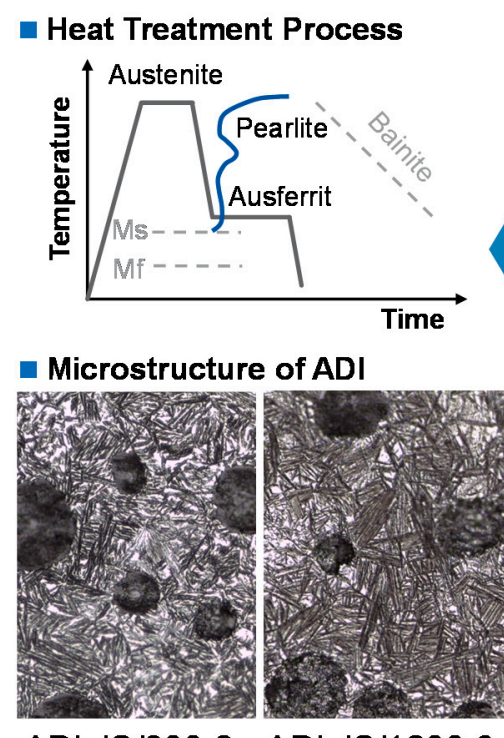

ADI JS/900-8 ADI JS/1200-3

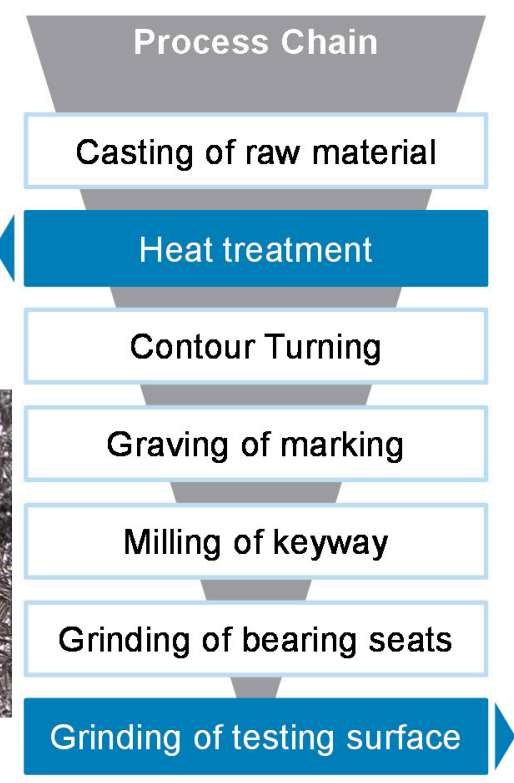

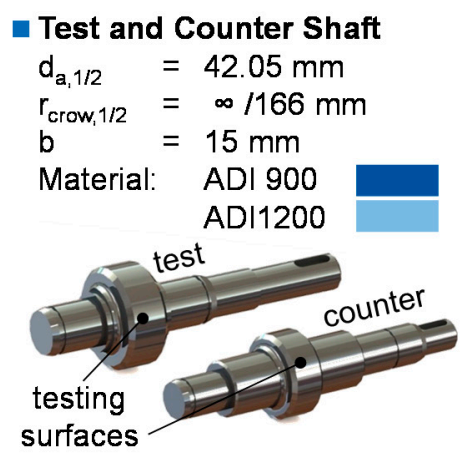

Arithm. Aver. Roughness Ra

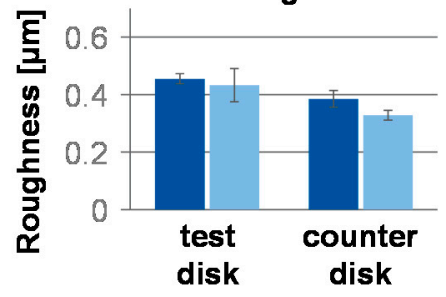

Figure 3. Manufacturing chain and production quality of ADI test parts.

The tensile properties were obtained by machining samples taken from castings in the disk area, according to the ISO17804 standard [15] (compare Table 2). The hardness was measured on three samples of the heat treatment batch in order to determine the statistical average of the material grade and, for this reason, is reported as a range of values.

Table 2. Mechanical Properties of ADI JS/900-8 and ADI JS/1200-3.

\begin{tabular}{ccccc}
\hline Material Grade & Tensile Strength & Yield Strength & Frac. Elongation & Brinnell Hardn. \\
\hline ISO17804 [15] & $R_{m}\left[\mathrm{~N} / \mathrm{mm}^{2}\right]$ & $R_{P 0.2}\left[\mathrm{~N} / \mathrm{mm}^{2}\right]$ & $A_{5}[\%]$ & $H B W$ \\
\hline ADI JS/900-8C & 925 & 723 & 8.2 & $294-311$ \\
\hline ADI JS/1200-3C & 1241 & 945 & 4.1 & $378-392$ \\
\hline
\end{tabular}

The macrogeometry of the disk contact was a cylindrical point contact, which was successfully applied in different studies [16-18]. The test and counter disks have an outer diameter $d_{a}=42.05 \mathrm{~mm}$ and a width $b=14 \mathrm{~mm}$ (Figure 3 , right). The test disk is cylindrical without a crowning $\left(r_{\text {crown }}=\infty\right)$, while the counter disk has a crowning with a radius $r_{\text {crow }, 2}=166 \mathrm{~mm}$ in the axial direction. The reason for the crowning is a higher maximum contact pressure, as well as the avoidance of pressure peaks at the contact edges. Besides the material properties, the surface roughness is analyzed for the test and counter disks for both ADI grades, as shown in Figure 3. The arithmetic mean roughness for the test disks amounts to $R a_{\text {test }}=0.43-0.45 \mu \mathrm{m}$, and for the counter disks it amounts to $R a_{\text {counter }}=0.32-0.38 \mu \mathrm{m}$ $(R z \approx 2.9 \mu \mathrm{m})$. Considering the scatter of the measurements, the roughness of the variants ADI900-8 and ADI1200-3 is comparable. Hence, the test parts for the different variants do not vary, with the exception of the material properties. The investigation of the contact fatigue for ADI is compared with one steel variant (42CrMo4) in order to classify the potentials of both gear materials. The contact 
fatigue results are taken from GoHRITz [19]. The quenched and tempered steel 42CrMo4 has a hardness

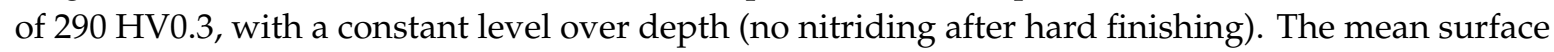
roughness is $R a=0.40-0.45 \mu \mathrm{m}$ and therefore in the same range as the ADI parts. Instead of a point contact, the contact geometry is a line contact with a width of $b=15 \mathrm{~mm}$. Further details of the material properties and testing conditions are documented in [19].

\subsection{Test Rig and Test Conditions}

The disk-on-disk test rig is an economic alternative to the back-to-back gear test rig for the investigation of contact fatigue strength. The disk-on-disk contact represents the tribological conditions at a specific point on the path of contact. The conceptual idea of the transfer from the tooth contact to the disk contact is shown in Figure 4. Each contact point on the path of contact can be described by the local radii of curvature, the tangential velocities of pinion and gear, as well as the local normal force. As a result, an analogy model can be derived that is very similar to a disk contact. For further simplification of the analogy model, the radius of the disks is changed in such a way that the test disk and counter disk have the same radius (Figure 4). In the final experimental setup, different rotational speeds of the disks and the application of a normal force need to be realized in order to complete the tribological system.

Gear Tooth Contact

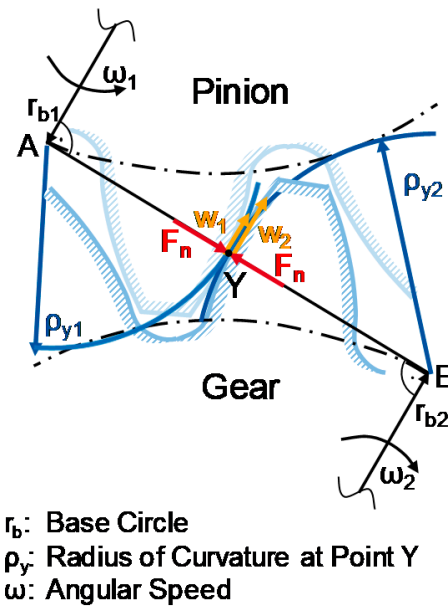

Analogous Modell
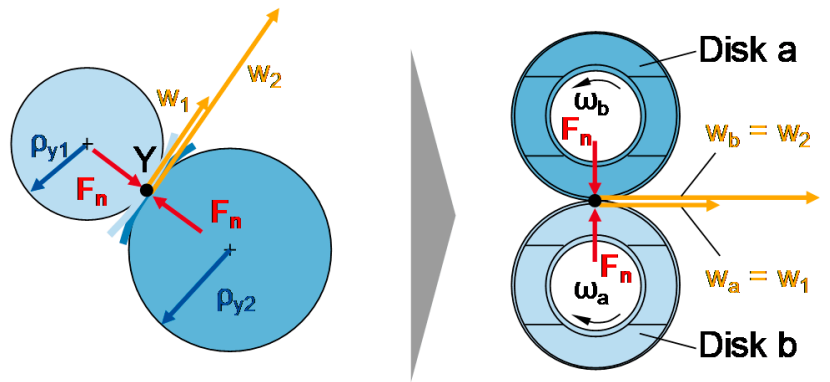

Figure 4. Transfer of the gear test to the disk-on-disk test.

An advantage of this testing concept, when compared to the gear tests, is a reduction of costs, as the disks are cheaper than gears and the test rigs are smaller (a factor 3 smaller than the back-to-back test rig) [20]. Furthermore, the testing principle allows for the investigation of the influence of a single combination of loads on strength and efficiency, since the load and kinematic conditions do not vary when compared to the gear contact. Hence, the sliding, curvature and normal force are independent of each other.

The experimental investigations are performed on the WZL disk-on-disk test rig (Laboratory for Machine Tools and Production Engineering WZL of RWTH Aachen University, 52074 Aachen, Germany), as shown in Figure 5 [18,19]. The test rig consists of the housing, including two shafts and the pressure piston, a gearbox and an electric motor. The gearbox determines the different rotational speeds of the disks and therefore the slippage of the rolling-sliding contact. The normal force is applied by a hydraulic piston in order to ensure a defined Hertzian pressure in the contact area. The test rigs are jet-lubricated. In case of damage, the test is stopped by a vibration monitoring system. 
- Test Rig Data

$\begin{array}{ll}\mathbf{a} & =42.05 \mathrm{~mm} \\ \mathbf{n} & =3000 \mathrm{~min}^{-1} \\ \mathbf{s} & =-28 \% \\ \mathbf{Q}_{\text {Oil }} & =1.5 \mathrm{l} / \mathrm{min} \\ \mathrm{T}_{\text {Oil }} & =90{ }^{\circ} \mathrm{C}\end{array}$

- Key

1 Test Shaft (cylindrical)

2 Counter Shaft (crowned)

3 Pressure Piston

4 Housing

5 Pressure Lever

6 Motor

7 Gearbox (Slippage)

8 Pressure Reservoir

9 Pressure Aggregate

10 Lubricant Circulation
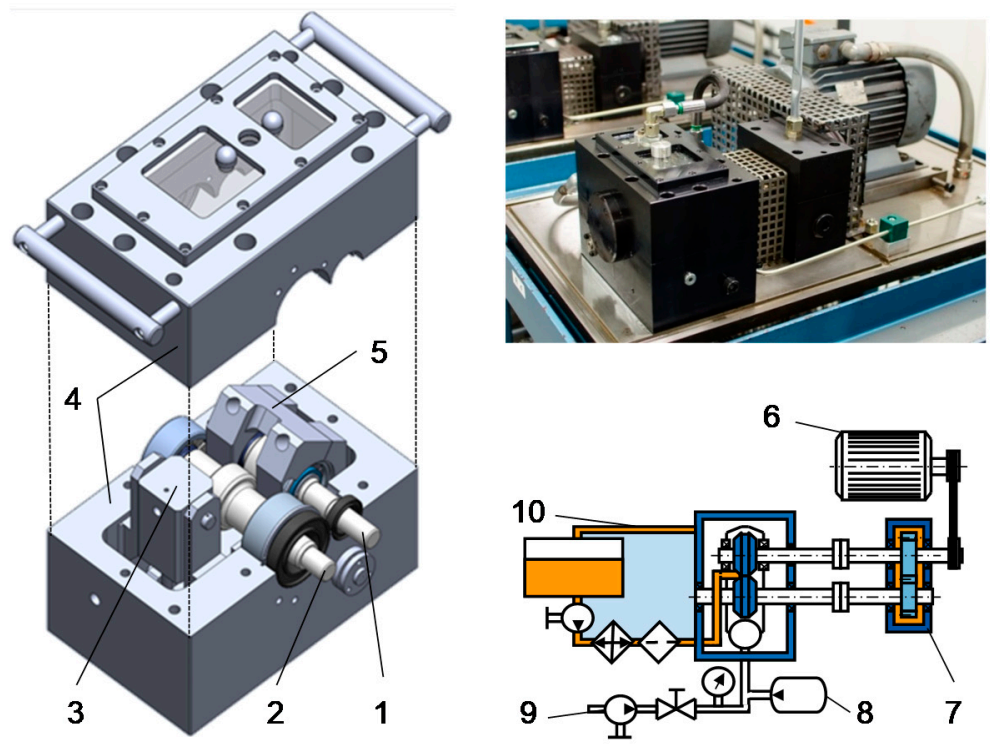

Figure 5. WZL disk-on-disk test rig for rolling-sliding contact fatigue investigations.

For both materials, the testing conditions of the investigation are defined so as to be close to the tribological conditions of the tooth flank contact. Parallel to the pitting critical area on case-hardened gears, the slippage is set to $s=-28 \%$ [19]. This condition represents the tribological contact condition at the lower point of single contact of a spur gear type, which is often used for gear material investigations according to ISO 6336 (module $m_{n}=5 \mathrm{~mm}, \alpha_{n}=20^{\circ}, z_{1 / 2}=17 / 18$ ) [21,22]. The rotational speed of the test shaft is $n_{1}=3000 \mathrm{~min}^{-1}$. The running-in procedure is performed at a Hertzian pressure of $p_{H, \text { running-in }}=900 \mathrm{MPa}$ for $N_{\text {running-in }}=1.8 \times 10^{5}$ load cycles in order to flatten the surface asperities in the contact area of high loads. The applied oil type is FVA3A 4\% Anglamol (ISO VG100) for ADI grades. The oil inlet temperature is $T_{\text {Oil }}=90^{\circ} \mathrm{C}$.

In order to build a complete $\mathrm{S} / \mathrm{N}$ curve, the endurance limit and finite life strength are separately investigated. The material strength in the finite life region is determined on two-load stages, averaging the load cycles up to damage of three tests in a Weibull probability plot [23]. Afterwards the connection of the load cycles on each load level delivers the finite strength straight line. Furthermore, investigations are performed on single-load stages in the area of endurance strength. The testing sequence is performed according to the staircase method and evaluated according to the IABG method [13]. The limiting number of load cycles is $N_{\text {lim }}=5 \times 10^{7}$ load cycles. The test is monitored by continuous structure-borne noise monitoring and by visual inspection every $24 \mathrm{~h}$. In the case of exceeding the limiting number of load cycles without pitting damages, the test is stopped (limiting pitting size: $<4 \%$ of contact area).

\section{Results and Discussion}

\subsection{Contact Fatigue Strength}

Figure 6 summarizes the results of the contact fatigue investigation for the disk-on-disk tests. The diagram shows the Hertzian contact pressure (stresses) over the number of load cycles. For the pressure calculation, the Hertzian theory with a Young's Moduls $E_{A D I}=160,000 \mathrm{MPa}$ $\left(E_{\text {Steel }}=210,000 \mathrm{MPa}\right)$ and a Poisson's Ratio of $v_{A D I}=0.28\left(v_{\text {Steel }}=0.3\right)$ is applied. The result of each test is marked with a cross (pitting damage by surface fatigue) or a circle (run out, at least $5 \times 10^{7}$ load cycles). For the calculation of the endurance limit, at least nine tests are considered, according to the staircase method, for ADI grades. The finite life region is determined with six tests for both ADI variants, as described above. 


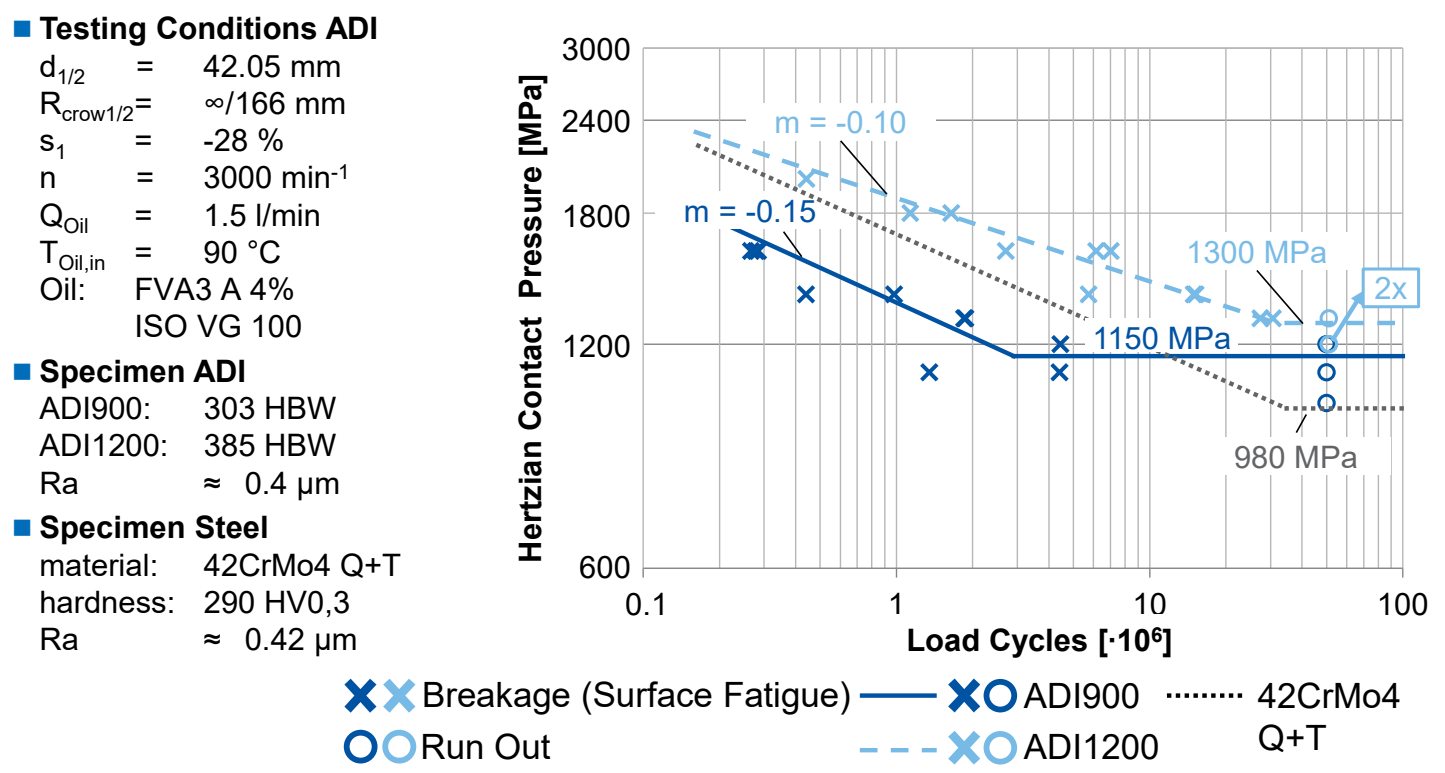

Figure 6. Comparison of the contact fatigue results for ADI900-8, ADI1200-3 and 42CrMo4.

The endurance limit for the variant ADI900-8 is $p_{H, l i m, A D I 900}=1150 \mathrm{MPa}$. According to expectations, the variant ADI1200-3 with a higher tensile strength increases the endurance limit for contact fatigue by $\Delta p_{H}=+13 \%$ up to $p_{H, l i m, A D I 1200}=1300 \mathrm{MPa}$ (Figure 6). The test results for both ADI variants follow the typical shape of an $\mathrm{S} / \mathrm{N}$ curve in the double logarithmic depiction. The finite life region can be approximated by a straight line, whereby the slopes for ADI900-8 and ADI1200-3 are comparable $\left(m_{A D I 900}=-0.15 ; m_{A D I 1200}=-0.10\right)$. The main difference between both $\mathrm{S} / \mathrm{N}$ curves is the transition area between the finite life and endurance limit. For the variant ADI1200-3, the load cycles of the transition area are $N_{T A, A D I 900}=35 \times 10^{6}$ load cycles. This confirms the limiting number of load cycles $\left(N_{\text {lim }}=5 \times 10^{7}\right.$ load cycles) and is comparable to the finite life region for case-hardened steels in gear applications according to ISO6336-5 [12]. In contrast, the load cycles of the transition area for ADI900-8 are $N_{T A, A D I 900}=2.6 \times 10^{6}$ load cycles. The runtime of all the tests of this variant does not exceed five million load cycles in case of the occurrence of a pitting damage. Hence, it appears to be safe to assume that the fatigue progress is not as important as the basic strength of the material for ADI900-8, because pitting damages occur close to the static strength. Compared to the quenched and tempered steel $42 \mathrm{CrMo} 4$ without nitriding, ADI's contact fatigue strength is higher and competitive. Therefore, $\mathrm{ADI}$ can be a strong alternative for gears made of $42 \mathrm{CrMo} 4$ without nitriding with regard to the contact fatigue strength, such as for application in ring gears.

\subsection{Pitting Characteristics and Microstructural Changes of ADI}

For a further understanding of the rolling-sliding contact fatigue behavior of ADI, the damage pattern and changes of the contact geometry are analyzed, as shown in Figure 7. For both ADI grades, the pitting damage shows the typical shell shape known from numerous investigations $[18,22,24]$. The tip of the outbreak points in the direction of the friction force, with reference to the test disk, which is comparable to the pitting characteristics of case-hardened steels [18]. Because of the point contact, the pitting damage always occurs in the center of the contact area. The size of the pitting is similar for ADI900-8 and ADI1200-3.

In order to gain knowledge of the running behavior of ADI in rolling-sliding contacts, the geometrical change after the test run is evaluated. The profiles of the test and counter disk are measured before, as well as after, testing and are aligned to each other using the unloaded area next to the contact area as the reference point. For both variants, the geometrical changes of the test disk are smaller than $\delta<2 \mu \mathrm{m}$. Several measurements confirm that these changes do not depend on the number of load cycles, especially when compared with the run-out tests. Therefore, it can be assumed 
that the geometrical changes result mostly from the loading during the running-in period and that there is no continuous increase of wear during the test run. Hence, the wear resistance of both ADI grades is sufficient for gear-typical rolling-sliding conditions.

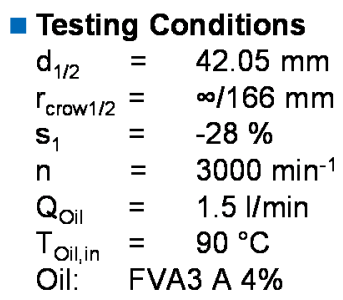

- Key

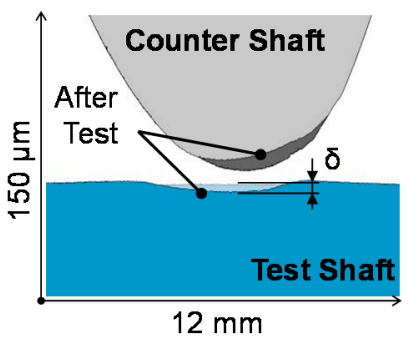

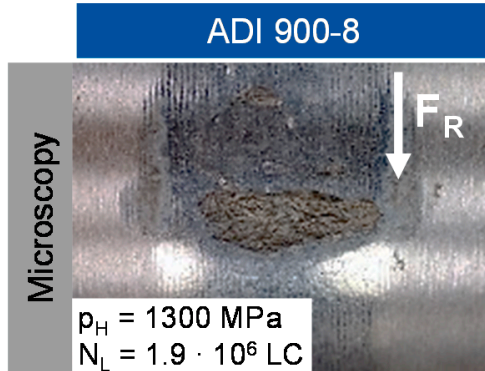

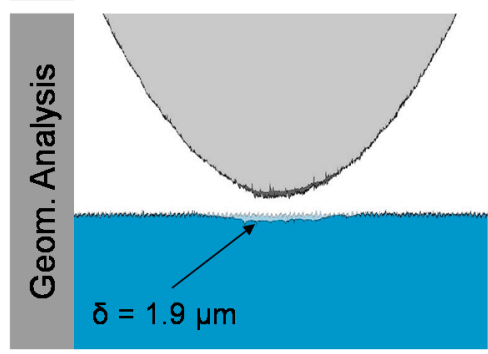

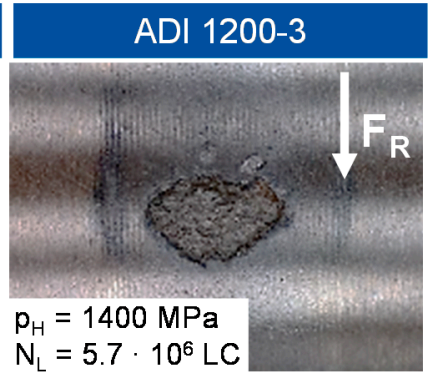

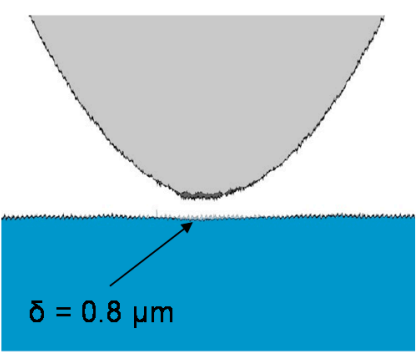

Figure 7. Analysis of the damage pattern and geometrical changes.

In order to gain a deeper understanding of the material changes during the loading period for ADI, measurements of the microstructure and microhardness are performed perpendicularly to the sliding direction for two run-out tests of both ADI variants ( $N_{\text {lim }}=5 \times 10^{7}$ load cycles) (Figure 8). The acting normal force causes a slight deformation of the graphite nodules, which are directly positioned below the surface ( $t \approx 10 \mu \mathrm{m}$; Figure 8 , left). In deeper regions of the surface area, visual inspections of the microstructure do not show changes when compared to the unloaded material. The graphite nodules still show a spherical shape, and the ratio of the structural elements appears similar in the unloaded and loaded areas. To quantify these visual evaluations of the microstructure, additional microhardness measurements are performed perpendicularly to the sliding direction (axial). The width of the measurement area is set to $b=8 \mathrm{~mm}$, with 100 single measurement points at a depth of $t_{H V 0.1}=100 \mu \mathrm{m}$ to the surface. The measurements points, positioned close to the graphite nodules, are excluded from the analysis, since the resulting hardness does not represent the average value of the basic structure of ADI. For both variants, there is no difference between the microhardness values at the contact area and at the unloaded areas (Figure 8, central). The average Vickers hardness for ADI900-8 is 451 HV0.1, and for ADI1200-3 it is 574 HV0.1. The results of the hardness measurements confirm the result of the microstructure analysis, according to which the loading is not sufficient to cause significant changes in the microstructure and material properties of the contact area.

For a deeper understanding of the pitting failure in the ADI parts, a material crack analysis is shown in Figure 8, on the right. The cracks mostly start from nodules and are observed mostly at a depth of $0 \mu \mathrm{m}<t<100 \mu \mathrm{m}$. The nodules represent certain kinds of imperfections in the material, where the local stress increases as a result of notch effects or differences in the Young's Modulus between the nodule and surrounding matrix. The cracks do not show any preferred direction and start from several positions around the nodule. This crack pattern can be reduced to the multiaxial stress state of a rolling-sliding contact [25-27]. In this case, the critical stress changes its direction, depending on the rolling position or rather the point in time. The cracks are similar for both ADI grades, which are run-out tests with a loading of $p_{H}=1200 \mathrm{MPa}$. 

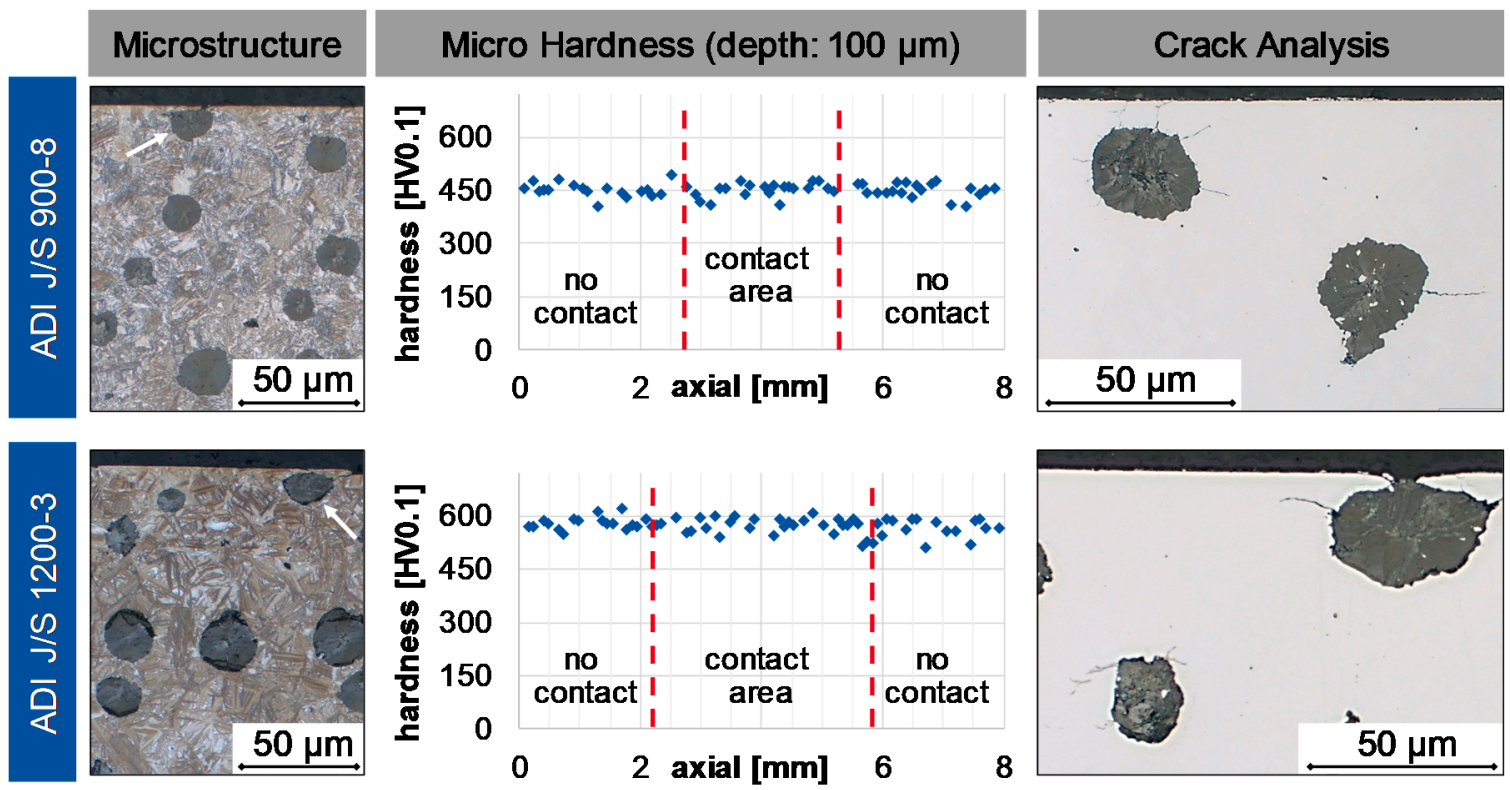

Figure 8. Analysis of the microstructure and microhardness of ADI after the test run.

\section{Conclusions}

Besides newly developed materials for drive technologies, Austempered Ductile Iron (ADI) shows a high potential, based on its basic material properties, for applications in gear components. For example, ADI can be used to pursue the integrated design of different components, such as the housing and ring gear of a planetary gearbox. Using ADI, the assembly space, number of parts and, hence, production costs can be reduced. Research on the rolling-sliding contact fatigue of ADI is mandatory in order to enable the application of ADI and to support engineers with reliable design guidelines for this material.

In this paper, the contact fatigue of two ADI grades (ADI J/S900-8; ADI J/S1200-3) is investigated by disk-on-disk tests. The disk-on-disk contact is an analogy model of the tooth contact and represents the tribological conditions at a specific point on the path of contact. The experimental results cover the endurance limit, as well as the short time fatigue behavior, for both ADI variants. As was expected, the contact fatigue strength of ADI1200-3 is higher than the endurance limit of ADI900-8. In the short time fatigue region, the load cycles until failure follow the typical shape of an $\mathrm{S} / \mathrm{N}$ curve in a double logarithmic depiction. In comparison to the quenched and tempered steel $42 \mathrm{CrMo} 4$ without nitriding, both ADI grades perform better, but do so in the same range.

The damage pattern of both ADI grades is comparable to steel and shows the typical pittings shell shape known from numerous investigations. With the exception of geometrical changes caused during the running-in period, there is no increasing wear for both ADI variants depending on the number of load cycles. The microhardness measurements before and after the loading confirm that there are no local hardening effects caused by the loading. To summarize the investigations on contact fatigue strength, ADI is particularly suitable for gear applications because of its high wear resistance and predictable contact fatigue based on its $\mathrm{S} / \mathrm{N}$ curve behavior.

Author Contributions: Conceptualization, F.G. and D.M.; funding acquisition, J.B.; investigation, F.G. and D.M.; methodology, F.G. and D.M.; project administration, F.G.; resources, S.M., E.V. and C.B.; supervision, E.V. and C.B.; writing-original draft, F.G.; writing-review \& editing, D.M., S.M. and J.B. All authors have read and agreed to the published version of the manuscript.

Funding: This research was funded by the Research Association for Power Transmission Engineering (FVA), grant number "FVA 822" and the German Federation of Industrial Research Associations (AiF), grant number 19843.

Conflicts of Interest: The authors declare no conflict of interest. The funders had no role in the design of the study; in the collection, analyses, or interpretation of data; in the writing of the manuscript, or in the decision to publish the results. 


\section{Appendix A}

Table A1. Nomenclature.

\begin{tabular}{|c|c|c|}
\hline Symbol & Unit & Definition \\
\hline a & $\mathrm{mm}$ & Center distance \\
\hline A & $\%$ & Fracture elongation \\
\hline $\mathrm{b}$ & $\mathrm{mm}$ & Width of disk \\
\hline $\mathrm{d}_{\mathrm{a}}$ & $\mathrm{mm}$ & Outer diameter of disk \\
\hline $\mathrm{E}$ & $\mathrm{N} / \mathrm{mm}^{2}$ & Young's modulus \\
\hline $\mathrm{F}_{\mathrm{N}}$ & $\mathrm{N}$ & Normal force \\
\hline $\mathrm{F}_{\mathrm{R}}$ & $\mathrm{N}$ & Friction force \\
\hline HBW & - & Brinnell hardness \\
\hline $\mathrm{HV}$ & - & Vickers hardness \\
\hline $\mathrm{m}$ & - & Slope of time yield straight \\
\hline $\mathrm{m}_{\mathrm{n}}$ & $\mathrm{mm}$ & Normal module \\
\hline $\mathrm{n}$ & $\min ^{-1}$ & Rotational speed \\
\hline $\mathrm{N}$ & - & Number of load cycles \\
\hline $\mathrm{p}_{\mathrm{H}}$ & $\mathrm{MPa}$ & Hertzian contact pressure \\
\hline $\mathrm{Q}$ & $\min ^{-1}$ & Volume flow rate \\
\hline $\mathrm{r}_{\text {crown }}$ & $\mathrm{mm}$ & Radius of disk crowning \\
\hline$r_{b}$ & $\mathrm{~mm}$ & Base circle radius \\
\hline $\mathrm{Ra}$ & $\mu \mathrm{m}$ & Arithmetical average roughness \\
\hline $\mathrm{Rz}$ & $\mu \mathrm{m}$ & Average peak-to-valley height \\
\hline $\mathrm{R}_{\mathrm{m}}$ & $\mathrm{N} / \mathrm{mm}^{2}$ & Tensile strength \\
\hline $\mathrm{R}_{\mathrm{p} 0.2}$ & $\mathrm{~N} / \mathrm{mm}^{2}$ & Yield strength \\
\hline $\mathrm{S}$ & $\%$ & Slippage \\
\hline $\mathrm{t}$ & $\mu \mathrm{m}$ & Depth \\
\hline $\mathrm{T}$ & ${ }^{\circ} \mathrm{C}$ & Temperature \\
\hline $\mathrm{w}$ & $\mathrm{m} / \mathrm{s}$ & Tangential speed \\
\hline$z_{1 / 2}$ & - & Number of teeth \\
\hline$\alpha_{\mathrm{n}}$ & $\circ$ & Normal pressure angle \\
\hline$\delta$ & $\mu \mathrm{m}$ & Amount of plasticdeformation of disk \\
\hline$v$ & - & Poisson's ratio \\
\hline$\rho$ & $\mathrm{mm}$ & Radius of curvature \\
\hline$\omega$ & $\mathrm{s}^{-1}$ & Angular speed \\
\hline
\end{tabular}

\section{References}

1. Zimba, J.; Simbi, D.J.; Navara, E. Austempered Ductile Iron: An Alternative Material for Earth Moving Components. Cem. Concr. Compos. 2003, 25, 643-649. [CrossRef]

2. Wittwer, U.; Rechsteiner, A. ADI-Ein moderner Werkstoff mit vielfältigem Potenzial. Cast. J. 2005, 18, 4-6.

3. Lefevre, J.; Hayrynen, K.L. Austempered Materials for Powertrain Applications. J. Mater. Eng. Perform. 2013, 22, 1914-1922. [CrossRef]

4. Magalhaes, L.; Seabra, J.; Sá, C. Contact fatigue behaviour of artificially indented austempered ductile iron (ADI) discs. Tribol. Ser. 2001, 39, 469-482.

5. Dommarco, R.C.; Bastias, P.C.; Dall'O, H.A.; Hahn, G.T.; Rubin, C.A. Rolling Contact Fatigue (RCF) resistance of Austempered Ductile Iron (ADI). Wear 1998, 221, 69-74. [CrossRef]

6. Duarte, A.; Seabra, J.; Santos, H.M.C.M. ADI Behaviour under Twin-Disc Contact Fatigue Tests. Key Eng. Mater. 2002, 230, 218-221. [CrossRef]

7. Standard. Gießereiwesen-Ausferritisches Gusseisen Mit Kugelgraphit; DIN 1564; Beuth: Berlin, Germany, 2012.

8. Keough, J.R.; Lefevre, J. It Is Time to Include Austempered Ductile Iron (ADI) in the International Gear Standards; 2013; pp. 1-15.

9. Standard. Austempered Ductile Iron for Gears; AGMA 939-A07; American Gear Manufacturers Association: Alexandria, VA, USA, 2007.

10. Nofal, A. ADI-The New Dream Material for Gear Designers. In Proceedings of the 71st World Foundry Congress, Bilbao, Spain, 19-21 May 2014. 
11. Standard. Calculation of Load Capacity of Spur and Helical Gears-Part 2: Calculation of Surface Durability (Pitting); ISO 6336 Part 2; ISO Copyright Office: Geneva, Switzerland, 2008.

12. Standard. Calculation of Load Capacity of Spur and Helical Gears-Part 5: Strength and Quality of Materials; ISO 6336 Part 5; ISO Copyright Office: Geneva, Switzerland, 2015.

13. Hück, M. Ein verbessertes Verfahren für die Auswertung von Treppenstufenversuchen. Werkstofftechnik 1983, 24, 406-417. [CrossRef]

14. Lebensdauerstatistik. Statistische Methoden zur Beurteilung von Bauteillebensdauer und Zuverlässigkeit und ihre Beispielhafte Anwendung auf Zahnräder; Höhn, B.-R., Zenner, H., Eds.; FVA (Forschungsvereinigung Antriebstechnik e.V.): Frankfurt, Germany, 1999.

15. Standard. Founding-Ausferritic Spheroidal Graphite Cast Irons_Classification; ISO 17804; ISO Copyright Office: Geneva, Switzerland, 2005.

16. Bagh, A. Auslegung PVD-Beschichteter Stirnräder. Ph.D. Thesis, RWTH Aachen University, Aachen, Germany, 2015.

17. Bugiel, C. Tribologisches Verhalten und Tragfähigkeit PVD-Beschichteter Getriebe-Zahnflanken. Ph.D. Thesis, RWTH Aachen University, Aachen, Germany, 2009.

18. Löpenhaus, C. Untersuchung und Berechnung der Wälzfestigkeit im Scheiben-und Zahnflankenkontakt. Ph.D. Thesis, RWTH Aachen University, Aachen, Germany, 2015.

19. Gohritz, A. Ermittlung der Zahnflankentragfähigkeit Mittlerer und Grosser Getriebe durch Analogieversuche. Ph.D. Thesis, RWTH Aachen University, Aachen, Germany, 1982.

20. Börnecke, K. Beanspruchungsgerechte Wärmebehandlung von Einsatzgehärteten Zylinderrädern. Ph.D. Thesis, RWTH Aachen University, Aachen, Germany, 1976.

21. Empfehlungen zur Vereinheitlichung von Tragfähigkeitsversuchen an Vergüteten und Gehärteten Zylinderrädern; Stahl, K.; Tobie, T.; Matt, P. (Eds.) FVA (Forschungsvereinigung Antriebstechnik e.V.): Frankfurt, Germany, 2012.

22. Tobie, T. Zur Grübchen- und Zahnfusstragfähigkeit Einsatzgehärteter Zahnräder: Einflüsse aus Einsatzhärtungstiefe, Wärmebehandlung und Fertigung bei Unterschiedlicher Baugröße. Ph.D. Thesis, TU München, München, Germany, 2001.

23. Klocke, F.; Brecher, C. Zahnrad- und Getriebetechnik. Auslegung-Herstellung-Untersuchung-Simulation, 1st ed.; Carl Hanser: München, Germany, 2017; ISBN 9783446430686.

24. Ding, Y.; Gear, J.A. Spalling depth prediction model. Wear 2009, 267, 1181-1190. [CrossRef]

25. Elstorpff, M.-G. Einflüsse auf die Grübchentragfähigkeit Einsatzgehärteter Zahnräder bis in das Höchste Zeitfestigkeitsgebiet. Ph.D. Thesis, TU München, München, Germany, 1993.

26. Liu, J. Weakest link theory and multiaxial criteria. In Proceedings of the 5th International Conference on Biaxial/Multiaxial Fatigue and Fracture, Crakow, Poland, 8-12 September 1997; pp. 45-62.

27. Liu, J. Beitrag zur Verbesserung der Dauerfestigkeitsberechnung bei Mehrachsiger Beanspruchung. Ph.D. Thesis, TU Clausthal, Clausthal-Zellerfeld, Germany, 1991.

(C) 2020 by the authors. Licensee MDPI, Basel, Switzerland. This article is an open access article distributed under the terms and conditions of the Creative Commons Attribution (CC BY) license (http://creativecommons.org/licenses/by/4.0/). 